\title{
Exploring migrant micro-entrepreneurs' use of social capital to create opportunity in South Africa's informal market: A qualitative approach
}

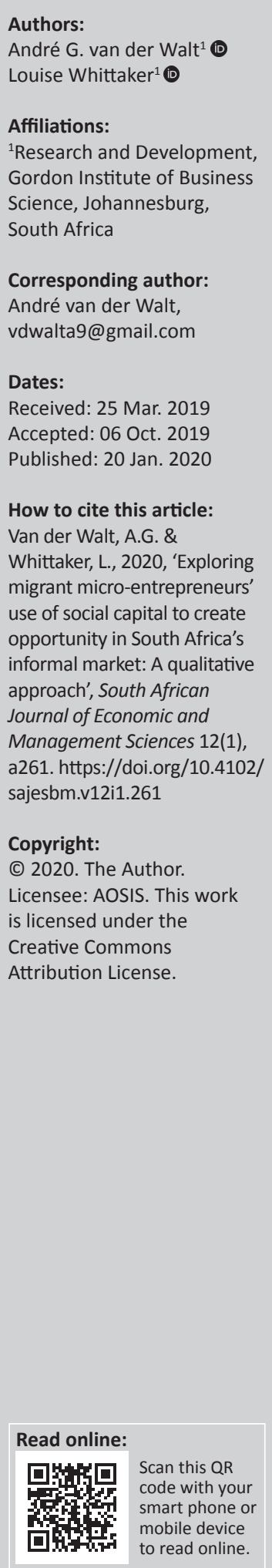

Background: Migrants operating micro-enterprises in rural communities of South Africa is a common phenomenon. These entrepreneurs live in communities they serve, and their enterprises are embedded in the 'social fabric' of these communities. Because economic and social value is entrenched in these symbiotic relationships, it fosters the belief that these microenterprises hold significant job creation potential. Social capital provides an excellent base to explore this topic in more detail.

Aim: The aim of this study was to explore why migrant micro-entrepreneurs operate enterprises in uncertain environments and how social capital contributes to migrant microentrepreneurial opportunity creation when contextualised in poverty.

Setting: The investigation focused on rural communities in two large regions of South Africa, Mahikeng and QwaQwa. Both regions are characterised by a large central hub with several rural villages scattered around it.

Methods: A qualitative research design helped to understand the process of opportunity creation. Entrepreneurs were selected through purposeful sampling to generate the data. Trustworthiness in the data was established by heightening transparency in the research process.

Results: Four themes emerged: life experience, social connections, opportunities and business engagement. Life experience provided insights into why these entrepreneurs operated enterprises in uncertain environments, and the themes collectively showed how these entrepreneurs use social relationships to access resources to create opportunity.

Conclusion: A visual framework and key contributions about how migrant microentrepreneurs gain access to resources, how opportunity contextualised in poverty was socially determined and the importance of entrepreneurial engagement provided academic and practical relevance in the field of entrepreneurship.

Keywords: emerging markets; community; micro-entrepreneur; migrant; opportunity creation; social capital.

\section{Introduction}

It is common to find numerous migrant micro-entrepreneurs in rural poor emerging markets, where the disenfranchised end user is the customer (George, McGahan \& Prabhu 2012:667). These enterprises are more often than not operated by an individual as a subsistence entrepreneur (Venugopal, Viswanathan \& Jung 2015; Viswanathan et al. 2014; Webb, Morris \& Pillay 2013). However, events or situations can motivate these entrepreneurs to move beyond the survival cycle to grow their business and thrive, which is termed 'transformative subsistence' entrepreneurship by Sridharan et al. (2014:488). According to them, transformative subsistence entrepreneurs pursue value-creating activities to self-enhance the growth of their businesses and improve the economic capacity of the community in which they operate.

As migrant micro-entrepreneurs very often live within the communities in which they operate their businesses, their micro-enterprises become embedded into the 'social fabric' of these communities (Viswanathan et al. 2012:161). It led Webb et al. (2013:2) to believe that it could also 'hold significant job creation potential'. Viswanathan et al. (2012), and later Viswanathan et al. (2014), suggested that this is because of the intense personal relationships that develop because of the multiple and continuous interactions, which create the need to commit socially to the 
community in order to sustain and stabilise the business. The economic and social values thus become entrenched in a symbiotic relationship between the disenfranchised end user and the micro-entrepreneur in a community setting.

As most of these entrepreneurs are asylum seekers (UNHCR 2015), governmental institutions should take note of and recognise the potential locked in the relationships these entrepreneurs have with disenfranchised end users. Microentrepreneurial contributions and the new stakeholder, the migrant micro-entrepreneur, have the potential to add value to socio-economic conditions in communities subjected to limited resources (McKinsey \& Company 2016).

On the contrary, a significant portion of micro-enterprises in deprived rural emerging markets is controlled by foreign national asylum seekers, which raises concerns about who controls end-user product flow to disenfranchised users. As opportunity in emerging markets weakens with slumping exchange rates and political uncertainty (McKinsey \& Company 2016), asylum seekers might choose to return to their home countries, and a collapse of the micro-entrepreneurial framework in rural deprived emerging markets might be inevitable. Understanding the strategies applied by these migrant micro-entrepreneurs and leveraging the insights that we can gain concerning their successes can benefit future endeavours by the government with policy drafting, and also micro-entrepreneurial programme development.

Moreover, because George et al. (2012) have shown that these micro-entrepreneurs are essential stakeholders, it is important to understand the critical link that bridges the external world (outsiders external to the community) with the internal world (embedded within the community). It becomes essential to understand why these micro-entrepreneurs operate businesses in these uncertain environments and also how they create opportunities when it is contextualised in poverty.

Answers to these questions might lie within social capital. However, does social capital in rural poor emerging markets inform and support entrepreneurial opportunity, or does social capital create boundary conditions that make it difficult for migrant micro-entrepreneurs to create feasible opportunities?

Looking at the literature, Hall et al. (2012) agreed with authors such as Karnani (2007) who persistently argued for the poor to be producers and entrepreneurs rather than merely the customers in inclusive growth initiatives. Prahalad (2012:6) viewed the bottom of the pyramid as a 'new source of radical innovation'. While Hall et al. (2012) supported this view, they went on to suggest that local innovation should be driven by the poor as entrepreneurs. Ansari, Munir and Gregg (2012), however, shifted the discussion towards capability transfer, proposing that it can help individuals to make more informed judgements. Calton et al. (2013) then stated:

[A]ttention must shift away from identifying which market niches to exploit and toward nurturing the capability of a community in poverty (via economic, cultural and infrastructure development) for a mutually advantageous advantage. (p. 722)

Still, it was Stuetzer et al. (2014:242) in particular who called 'for a deeper investigation of how (and the conditions under which) the region affects individual intentions and engagement'. Storti (2014) pointed out expressly the research need about immigrant entrepreneurial pathways that take shape through actors and personal resources, and the characteristics of the networks to which they belong. Also, Rooks, Klyver and Sserwanga (2016) proposed a qualitative design for future research to study the dynamics of the interplay between contextual culture, entrepreneurship and social capital, which this study adopted.

\section{Literature review Contextual conditions}

The poor and poverty have no clear definition and are viewed differently by different authors. Bradley et al.'s (2012:688) version of grouped views were used, namely, 'individual deficiency', 'structural failing', 'cultural deficiency' and poverty as a 'capacity or opportunity deficiency'.

As this study is concerned with opportunity creation, poverty from a 'capacity or opportunity deficiency' view seemed more appropriate, which is viewed as a consequence of a lack of economic and social capital that limits possibilities.

Focusing specifically on rural communities, Rivera-Santos and Rufín (2010), and later Rooks et al. (2016), have shown that rural and urban communities reflect differences in attributes, and according to Stuetzer et al. (2014) these regional characteristics can exert influence on entrepreneurial behaviour. Their study has shown that because regional characteristics are objective and operate as distil factors, they do not directly drive entrepreneurial behaviour. However, if the entrepreneur perceives it to be of value, it can influence behaviour. Metzger and King (2015) agreed, and further have shown, that these perceptions even play a determining role in how the opportunity is constructed. In line with this argument, Sruwig, Krüger and Nuwagaba (2019:8) more recently also highlighted environmental influences that affect informal businesses growth.

The term 'community' as used in this study was defined by Marti, Courpasson and Barbosa (2013) as a collective identity within the context of rural poor emerging markets. They held the view that 'a community becomes a working space allowing members to discover their capacities to act and to defend their rights' (Marti et al. 2013:10). They postulated that community members and external actor relationships could harvest social benefits towards specific actions and entrepreneurial creations, as well as challenge the community's world views. Social relations and social structures within such community entities, according to Ozdemir et al. (2016:49), could help entrepreneurs to 'enhance their reach to or facilitate the acquisition of valuable resources'. According to them, social relationships 
are embedded in social capital through either relational or structural embeddedness which provides different kinds of access to resources. Social capital, therefore, provides a gateway for migrant micro-entrepreneurs to accumulate resources in order to pursue or create opportunity (Daspit \& Long 2014).

\section{Opportunity creation and the entrepreneur}

According to Wood and McKinley (2010:66), an opportunity relies not only on the environment but also on the individual in that environment. They followed a constructivist perspective which argues that 'opportunities are produced through a process of social construction and cannot exist apart from the entrepreneur' (Wood \& McKinley 2010:66). In support, Metzger and King (2015:324) added that 'opportunities are enacted, dependant on the entrepreneurs' perceptions, interpretation, and understanding of environmental forces', and Ramoglou and Tsang (2016) suggested that entrepreneurial opportunity is actively created through subjective processes and social construction. It points to opportunity creation which states that opportunities cannot exist apart from the actions of the entrepreneur, opposed to opportunity discovery which views an opportunity as out there waiting to be discovered (Alvarez \& Barney 2007, 2014).

An entrepreneur in this sense is someone who tolerates uncertainty and believes that the environment presents an opportunity that could be feasible and fulfil a personal desire (Davidsson 2015; McMullen \& Shepherd 2006). Entrepreneurs who operate small firms that often consist of a single, selfemployed individual who commonly operates out of a local inhabitant's property are called micro-entrepreneurs (Webb et al. 2013).

Migrant micro-entrepreneurs, foreign national individuals who manage a micro-enterprise or enterprises in a country they are not citizens of (Kloosterman 2010), rely heavily on social relationships to access resources, especially in emerging markets (Webb et al. 2013).

In line with this argument, Leitch, McMullan and Harrison (2013:351) proposed a mindset of 'mutuality' when doing business in emerging markets. Mutuality indicates collaboration between interdependent entities, which implies trust, respect and collaborative working (Leitch et al. 2013; Marti et al. 2013; McKeever, Anderson \& Jack 2014). Since social capital has the means to provide access to resources (McKeever et al. 2014; Nahapiet \& Ghoshal 1998), which according to Gedajlovic et al. (2013:458) are 'knowledge, information, goodwill and trust', they also suggest that access is determined by the number and frequency of these interactions. The strength of these links is, therefore, regulated by bonding and bridging social capital. This study argues that it happens through the concept of 'mutuality', which emphasises social exchange and reciprocity (Leitch et al. 2013:351; Lioukas \& Reuer 2015), and also the concept 'habitus' which focuses more on an appreciation of the cultural context (McKeever et al. 2014:454).
Therefore, taking a subjective approach as suggested in the literature, and considering the environment and how the entrepreneur constructs opportunity within it, the model of Nahapiet and Ghoshal (1998) was used to ground this study. Although social capital is an old concept, its modern development centres on how the concept functions in different environments (Lee et al. 2019; Theodoraki, Messeghem \& Rice 2018). Other models, such as the schematic model of social capital and entrepreneurship, also advocate a multidimensional view. However, it views the structural dimension as an antecedent to the cognitive and relational dimensions, which excludes the structural dimension as a gateway to resources (Gedajlovic et al. 2013). And because the environment influences the way social capital dimensions function, two types of social capital dominates (Gedajlovic et al. 2013).

Nahapiet and Ghoshal's (1998) model, however, is unique in that it applies all three dimensions of social capital to produce intellectual capital through combination and exchange. Combination and exchange are influenced by the type of social capital that dominates, depending on contextual conditions. Two decades later, their framework still provides an excellent base to advance our understanding of social capital and its function in different settings (Daspit \& Long 2014; Lee et al. 2019; Theodoraki et al. 2018).

\section{Social capital}

According to Nahapiet and Ghoshal (1998:243), social capital is defined as the 'sum of the actual and potential resources embedded within, available through, and derived from the network of relationships possessed by an individual or social unit'. They proposed in their model that social capital has three dimensions and that each dimension underlies a series of themes (see Figure 1).

According to Nahapiet and Ghoshal (1998:252), the structural dimension was characterised by: (1) network ties, valuable sources of information which allowed benefits through access, timing and referrals - 'whom you know affects what you know', (2) network configurations, which provide the channels for information transmission recognised through properties such as density, connectivity and hierarchy associated with flexibility and ease of information exchange, and (3) appropriable organisation, which explains the context in which social capital is developed such as ties, norms and trust which can often be transferred to other contexts, although it would influence the patterns of social exchange.

The cognitive dimension was recognised through meaningful communication and shared stories. Nahapiet and Ghoshal (1998:254) recognised shared language as the means to communicate knowledge and postulated that language influences perceptions. They further suggested that language enhances combination capabilities through some overlap of knowledge between parties to the exchange. They also recognised that shared narratives involving the stories, myths and metaphors 'provide powerful means in 


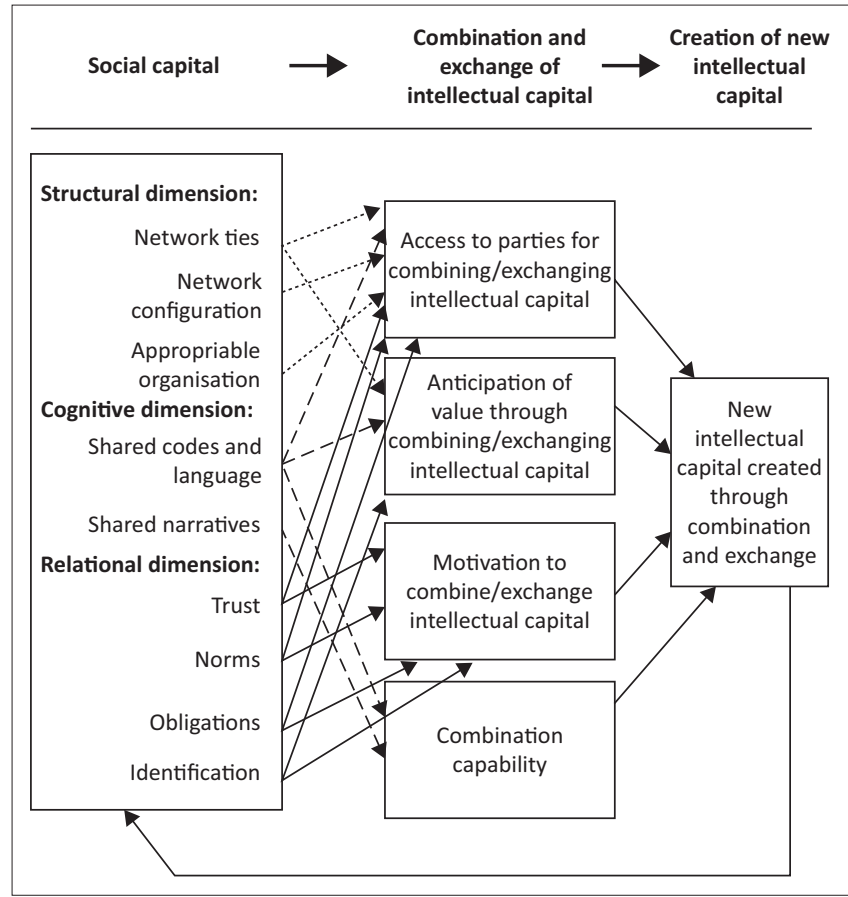

Source: Nahapiet, J. \& Ghoshal, S., 1998, 'Social capital, intellectual capital, and the organizational advantage', Academy of Management Review 23(2), 251. https://doi. org/10.5465/AMR.1998.533225

FIGURE 1: Model of social capital in the creation of intellectual capital.

communities for creating, exchanging and preserving rich sets of meaning'.

As the primary impact of the structural dimension is on the conditions of accessibility, the cognitive dimension focused on its influence on accessibility and combination capabilities. Daspit and Long (2014), however, made it clear later that the sources of social capital are embedded in the structural dimension and the resources in the cognitive and relational dimensions. They thus supported the claims by Gedajlovic et al. (2013) that the relational dimension develops out of the cognitive dimension through mutuality. Still, as Nahapiet and Ghoshal (1998) have shown, it cannot be ignored that the relational dimension is influenced by three conditions for the exchange of information. This is 'access to parties for exchange, the anticipation of value through exchange, and the motive of parties to engage in exchange' (Gedajlovic et al. 2013:254).

Accordingly, these conditions for exchange were grounded in: (1) trust, which is multidimensional and indicates the 'willingness to be vulnerable to another party' and the belief that an intended action of another was appropriate. They suggested that there exists a two-way interaction between trust and cooperation in that 'trust lubricates cooperation, and cooperation itself breeds trust' (Nahapiet \& Ghoshal 1998:255). (2) Norms, which represented 'a degree of consensus in a social system', exert influence on the exchange process through opening access, or create rigid boundaries for parties to exchange knowledge. (3) Obligations and expectations, which represented commitments to some activity in the future because of expectations developed through relationships. Obligations and expectations were likely to influence access and the motivation to combine and exchange knowledge. (4) Identification was introduced to present the belonging aspect of an individual within a group and thus it 'acts as a resource influencing both the anticipation of value to be achieved and the motivation to combine and exchange knowledge' (Gedajlovic et al. 2013:254-256).

As Gedajlovic et al. (2013:456) suggested mutuality to highlight the trust, respect and collaborative working elements of the relational dimension, they also claimed that the 'acquisition and management of social capital plays an essential role in the entrepreneurial success of both individuals and collectives'. Furthermore, they have shown that resources such as knowledge, information, goodwill and trust stem from relationships between individuals or collectives, and suggested that the 'frequency of these interactions; kinships; or the number/strength of ties lead to those resources' (Gedajlovic et al. 2013:458). With this in mind, both the bonding and bridging perspectives of social capital have to be considered as it has been shown that each perspective can produce different outcomes (Gedajlovic et al. 2013; McKeever et al. 2014; Rooks et al. 2016).

\section{The bonding perspective of social capital}

Firstly, the bonding perspective reflects value in social capital through strong, repeated social connections that focus on reciprocity, generating norms and increased trust (Gedajlovic et al. 2013). According to McKeever et al. (2014), social capital is strongly influenced by the context and the community in which it is embedded, and social capital thus influences how entrepreneurs in a community setting perceive opportunity. They suggest Bourdieu's (1990) notion of 'habitus' which claimed that the socio-economic context provides circumstances that increase repetitive behaviours and fosters a shared understanding of these behaviours. As 'habitus' is closely linked to the cultural capital of a community (McKeever et al. 2014), the norms, rituals and stories associated with this cultural context become essential.

Relating the bonding perspective with Nahapiet and Ghoshal's (1998) model of social capital, the structural and cognitive dimensions are activated. Close and robust bonding ties provide access to information with the anticipation of value, which means it is limited to individuals or collectives that share in these cultural norms, rituals and stories (McKeever et al. 2014). Therefore, when a bonding perspective is followed, entrepreneurial opportunities can be suppressed when dominant groups exclude subordinates from information sharing (Khayesi, George \& Antonakis 2014; Light \& Dana 2013).

Light and Dana (2013) identified such boundary conditions in their study which have shown that if the cultural capital of a community was positive towards entrepreneurship, substantial bonding social capital could be highly supportive of entrepreneurial opportunities. However, if the cultural capital did not support the notion of entrepreneurship, any entrepreneurial opportunity would be negatively affected. 
Khayesi et al. (2014:1323-1324) identified similar conditions when they highlighted 'kinship ties', which emphasise 'relationships by blood and marriage'. It demonstrates how strong ties could 'benefit or detract an entrepreneur's efforts to assemble resources and build a viable enterprise in a community setting' (Khayesi et al. 2014:1338).

Accordingly, Light and Dana (2013) and Khayesi et al. (2014) have shown that these relationships reflect rigid and strong tendencies to resist change. Therefore, because of the nature of 'habitus' and the broader cultural capital, extending relationships within this context was a slow process (McKeever et al. 2014).

\section{The bridging perspective of social capital}

Secondly, the bridging perspective, according to Gedajlovic et al. (2013:458), refers to actors who bridged structural holes to 'facilitate the diffusion of asymmetrical information'. Ozdemir et al. (2016:50) referred to structural holes as 'brokerage ego-networks in extending the entrepreneurs' reach to valuable resources' through actors not directly connected to and often unaware of one another. They claimed that resources derived from social capital were not always easily acquirable, or very often the resources available were not always valued.

McKeever et al. (2014) pointed out that the context very often determines the value that social capital holds and emphasised the critical role of the community in the entrepreneurial process. Marti et al. (2013) earlier proposed that external actors who work and interact with the community should maintain a sense of detachment, although they should physically be there. This notion emphasised 'working spaces' (Marti et al. 2013:27) which they maintained could create new resources and enhance information sharing when bridging the external world with the inner world of the community.

It means that the bridging perspective focused on external ties (loose ties) and was grounded in the relational dimension of Nahapiet and Ghoshal's (1998) model. According to the relational dimension, trust, norms, obligations and identification are central concepts in relationships, which motivate actors to cooperate in order to gain access to mutual benefits from these relationships. Leitch et al. (2013) and McKeever et al. (2014) have shown that this happens through 'mutuality'. They explicitly stated that when mutuality is absent, the entrepreneurial process is contractual and explicit, detracting from the benefits of information exchange. And because mutuality emphasises social exchange and reciprocity, it reflects the notion that each party to the exchange is required to repay the benefits they receive (Lioukas \& Reuer 2015).

These two perspectives of social capital, therefore, provide the means for access to resources. However, if the social structure of a community is dominated by habitus, extending relationships within such context will be much slower than when it is dominated by mutuality (McKeever et al. 2014).

\section{Aims and objective}

The aim of this research was, firstly, to understand why migrant micro-entrepreneurs operate micro-enterprises in uncertain environments and, secondly, how past and current social capital contribute to migrant micro-entrepreneurial opportunity creation when contextualised in poverty.

The overall objective of the study was to understand migrant micro-entrepreneurs in their natural environment - to extract valuable insights by exploring why and how these entrepreneurs do what they do.

\section{Methodology}

The researcher followed a qualitative exploratory research design that motivated the exploration and discovery of new insights. The emphasis of the study was on social capital and its effects on the micro-entrepreneurial opportunity, which is, as Payne et al. (2011:492) put it, 'the goodwill available to individuals or groups that are derived from the structure and content of an actor's social relationships'. Payne et al. (2011) explained that social capital research focuses on internal and external ties from an individual or collective perspective. This study followed an individual perspective that is grounded in the philosophy of interpretivism. It implies that the researcher attempted to understand each participant in his or her natural environment.

This study focused on South Africa's poor rural communities, which, according to London and Hart (2004, 2011), were characterised by typical earning per capita income equivalent to $\$ 3000$ per annum, or less. They also found that local enterprises operate primarily in the informal economy. These market characteristics presented challenges for the sustainability of life (Calton et al. 2013), for grasping opportunities to alleviate poverty and for developing the community economically through entrepreneurship (Alvarez \& Barney 2014). According to Calton et al. (2013), challenges to entrepreneurial actions included:

Limited education and work or entrepreneurial opportunities; dependence on cash or informal sources of credit; poor infrastructure and a lack of a market ecology to nurture entrepreneurial innovations; lack of patient capital to support the longer gestation period of innovative base of the pyramid business ventures; and rampant public and private corruption. (pp. 723-724)

Furthermore, the unit of analysis was focused on the individual's perceptions. Migrant micro-entrepreneurs live in the communities in which their micro-enterprises are located, and they therefore share commonalities with the poor. The researcher employed a non-probability purposeful sampling strategy and created diversity in the sample in two ways (Creswell \& Poth 2018). Firstly, different geographic locations in South Africa characterised by several rural villages around a central urban hub were used: Mahikeng in the North-West province because of several villages around the greater Mahikeng central hub and QwaQwa in the Free State with villages scattered around Phuthaditjhaba. 
As Marti et al. (2013) and Rooks et al. (2016) posited that a more collectivistic outlook in deprived rural environments can be expected when compared to an individualistic outlook in urban environments, the study concentrated on the communities in the surrounding villages. Secondly, two immigrant groups, Bangladeshi and Ethiopian nationals, were looked at because they dominated the micro-enterprises in these villages at the time.

According to Creswell and Poth (2018), the size of the sample in qualitative studies is dependent on data saturation. Sim et al. (2018) agreed and added that it could be problematic to determine a sample size $a$ priori for qualitative studies. They have indicated, however, that earlier studies can provide an excellent baseline to determine an initial sample number. This study, therefore, initially selected 10 migrant microentrepreneurs for interviews who matched the selection criteria and understood and spoke English, which, according to Sim et al. (2018), was an adequate number for a qualitative study doing interviews.

Data collection followed a narrative style (see Appendix 1) by listening to stories of the participants, who were given fictitious names (McCormick 2004). Atlas.ti, a computeraided qualitative data analysis software program, was used for data analysis. All interviews were audio-recorded, transcribed and then imported into Atlas.ti with memos and observation notes (Friese 2016). An iterative process was applied, collecting and analysing the data concurrently, which enabled the researcher to derive themes from the data collected.

After going back and forth, listening to the audio recordings and reading the transcripts and memos, codes were developed, and data saturation occurred at interview number 9. Axial coding, also known as code categories (Elo \& Kyngäs 2007), was used to group codes that belong together and link quotations to them to establish the meaning for each code group. In this way, each code group could be linked to a research question (Bloomberg \& Volpe 2012). Code clouds and code frequency tables in Atlas.ti were then used to rank the codes according to how many times they appeared in the data (Friese 2016). In other words, it highlighted the data points that carried more weight in the data. Lastly, the networking tool in Atlas.ti was applied to construct a global perspective of the data. It enabled the researcher to look at many possible relationships between the code groups and to go back and forth in the data to secure the themes (Friese 2016). Four major themes emerged, which were either associated with or affected by other sub-themes and code categories.

To validate the research process, firstly, ethical clearance was obtained from the Gordon Institute of Business Science to generate data. Secondly, a framework matrix was used, which was developed by Leitch, Hill and Harrison (2010:74) to allow transparency in all three domains of the research process: research design and data collection, data analysis and data interpretation. The framework was adopted for this study in an attempt to strengthen the trustworthiness of the data. It focusses on ethical justification, substantive justification and researcher quality. These three elements of justification had implications in all three domains of the research process. As qualitative studies involve interpretation, which is subject to the researcher's frame of mind and can be influenced by world view, educational level, background and cultural value system (Shepherd \& Sutcliffe 2011), such studies need to be justified.

Firstly, the ethical justification was ensured by staying within the ethical framework specified by the Gordon Institute of Business Science at all times. Also, care was taken to facilitate the data collection process. Pilot interviews helped to identify and rectify any leading questions and questions that had the potential to cause harm. During analyses, transcriptions were shared with participants to ensure that the data were captured correctly. Finally, during interpretations, the researcher continuously asked the question 'so what does this mean in the context of the study?' to search for deeper insights and retain thinking within the framework of the study.

Secondly, to ensure substantive justification, the researcher attempted to control subjective interferences. The researcher triangulated observations, which were documented in memos, with each interview, to support and strengthen the researcher's understanding of the actual meanings attached to phrases used by respondents (Creswell \& Poth 2018). Also, throughout the interpretation phase, the researcher applied an iterative process in order to confirm that the appropriate meanings were attached to each code, category and theme during the analysis phase.

Thirdly, the researcher's background in psychology and sociology influenced the research design positively, which provided a foundation to support the quality of the research, together with continual openness in the entire research process.

\section{Ethical consideration}

Gordon Institute of Business Science Ethical Committee approved ethical clearance (Protocol Number: Temp201601944) to conduct this study.

\section{Findings}

From the data, four major themes emerged: life experience, social connections, opportunities, and business engagement. Initially, during analysis, codes and code categories were developed, and data points were ranked according to code clouds and code frequency tables. Considering how the code categories relate to different research questions, a network view was constructed, which showed all codes and code categories in relation to one another. Patterns started to develop that first pointed to life events, a critical determinant in our understanding of research question 1 . This theme was termed 'life experience'. In light of research question 2, 
further analysis continuously pointed to patterns that related to social relationships, which led to the theme of social connections. To make sense of this overpowering theme, why and how questions were asked, which allowed two other patterns to emerge: for the opportunity and through business actions. These themes were then termed 'opportunity' and 'business engagement'.

Life experience firstly was related to social relationships, which included exposure by the family who owned businesses or respondents who worked in stores. It was also strongly affected by social judgement, manipulation and frustrations, as Rasta from QwaQwa showed:

'I am a Christian and I respect the people and I believe in God ... but South African people Sunday they are going to church and maybe Monday they have a strike and they will take your stuff, your property is damaged. I don't know which kind of church is that.' (Rasta, a male shop owner from QwaQwa, 20 September 2016 at $12: 20)$

It showed a reluctance to bond more deeply with the community.

Still, why do these entrepreneurs operate micro-enterprises in highly uncertain environments? James from QwaQwa explained:

'[O]ur economy was down, and my father was a soldier and he only gets his pension and it's too little, it's R300 and something. I was not getting good money and my life was in trouble, so I decided to come to South Africa.' (James, a male shop owner from QwaQwa,12 September 2016 at 07:15)

James, therefore, highlighted his country's weak economy as one reason to seek opportunity elsewhere, while others also highlighted political conflict and violence as reasons to seek opportunity elsewhere.

The data, therefore, have shown that the theme 'life experience' reflects past and current relationships, together with social issues, that can exert influence on their choices to connect socially in future.

Secondly, social connections were associated with the opportunities that were constructed through these connections. The data revealed business and community connections, which provided evidence to support how social capital contributes to opportunity creation. Business connections originated mostly from other same nationality micro-entrepreneurs, partnerships with others of the same nationality, and family and close relatives. When referring to his people, Michael from Mahikeng asserted:

'[W]hen we are working together we teach each other and learn from each other' (Michael, a male shop owner from Mahikeng, 13 September 2016 at 14:34).

Differences, however, existed between the Ethiopian and Bangladeshi nationals when looking at support and business activities. As less support offers fewer opportunities to extend their social connections, a higher emphasis is placed on community connections. Polash, a Bangladeshi national from Mahikeng, responded adamantly:

'In business if you treat people good then you will have a good relationship and they will come to the shop, the customer is always right ... I am living with these people, I don't want someone to hate me.' (Polash, a male shop owner from Mahikeng, 13 September 2016 at 11:23)

On the other hand, Ethiopian nationals were more focused on assisting and supporting one another personally, growing their respective businesses together.

The data also revealed that value was distributed from both ends. Solomon from QwaQwa admitted:

'[T]here is a lot of support, we help each other. Like my shop got burnt in 2011 and the women and the boys ... they came and said we want to donate for you Solomon, everyone likes to help me.' (Solomon, a male shop owner from QwaQwa, 12 September 2016 at 10:42)

The community shows a willingness to assist, whereas the respondents provide value to the community by allowing them to buy products on credit.

Unfortunately, crime and corruption formed barriers for businesses, which inadvertently affect the social relationships in the community negatively, as Shakil from Mahikeng shared his experience with corrupt police officials. He claimed that officials demanded free merchandise on a regular basis in turn for services that should be free of charge:

'I asked them where is the money and they said they are police so they don't have to pay. Then they said to me where is your asylum .... and the only people that are supposed to ask us are the people at the home affairs, so they were only asking because I asked them to pay for the things that they took.' (Shakil, a male shop owner from Mahikeng, 13 September 2016 at 12:58)

Social connections, as shown by the data, are therefore shaped by business and community connections which are very often degraded by crime and corruption.

The third major theme, opportunity, was shown to be socially determined in a poor rural context, by way of social connections. As respondents' intentions were to search for an opportunity for a better life and not to start a business, their social connections steered them towards entrepreneurial opportunities.

Solomon from QwaQwa explained that a friend initially provided him with the opportunity to sell bed sheets, clothes and household items; however, he never received his full commission on goods sold:

'[E]very month I collect he would give me money for food and rent only' (Solomon, a male shop owner from QwaQwa, 12 September 2016 at 10:13).

Still, newly formed social connections allowed him to start his micro-enterprise.

It was the case with two other respondents, although in these two cases, past connections came into play during 
opportunity creation. One respondent had access to a small number of funds and borrowed the remainder from his brother to start a small trading store. Shakil, a male shop owner from Mahikeng, had a similar situation:

'I asked my father and he gave me some money, and I asked my other friend and another "homie" ... then I opened my own shop.' (Shakil, a male shop owner from Mahikeng, 13 September 2016 at $12: 46)$

Both respondents used their newly acquired community connections to position their stores strategically.

It can therefore be argued that opportunity was determined by respondents' social connections fuelled by personal aspirations in an uncertain environment. James from QwaQwa showed, exposing the need to excel in business:

'Back in Ethiopia my friends have made progress, those I used to work with have progressed, now holding bigger positions, they have houses, so if I go back there I need to have something tangible to show that I have worked as well.' (James, a male shop owner from QwaQwa, 12 September 2016 at 07:38)

Business engagement, therefore, emerged as the fourth and last theme. One respondent declared that he regularly deposited money into his father's account in his home country, for his father to save the money on his behalf. He claimed to have enough saved to return to his home country and purchase a property. Yet, another respondent, James from QwaQwa, admitted the difficulties that he experienced:

'When I came here to South Africa, I told myself that I want to make money and then go back to Ethiopia and buy things I need and settle down ... but then things didn't go the way I thought. Conditions change every day ... every time I tell myself that I am doing this and that but when the day arrives something else happens ... I think next year I am going to grow by God's grace ... this place is not doing great so hopefully I can move.' (James, a male shop owner from QwaQwa, 12 September 2016 at 07:37)

Therefore, it exposes aspirations and the uncertainty of the environment. It also indicates that the respondents perceive their situation as temporary.

Interestingly, the evidence also showed that while some micro-entrepreneurs associated their situation with subsistence entrepreneurship, the majority opened second and third enterprises to grow beyond subsistence.

\section{Discussion}

\section{Key findings}

As the data agreed with entrepreneurship literature that social capital affects opportunity creation, the data also added to literature in three ways. Firstly, migrant micro-entrepreneurs did not embed themselves into the community to extract benefits as the bonding perspective suggested; instead, they used a bonding perspective to draw resources from their own formed community like friends, direct family and relatives.

Secondly, the data showed that opportunity, contextualised in poverty, was socially determined. It indicates that the social structure of the migrant micro-entrepreneur is crucial for opportunity creation and that mutuality and habitus unlock different kinds of resources that become available through these social connections. Thirdly, active engagement by the entrepreneur is needed. However, the data showed that aspirations are equally crucial to subsistence entrepreneurs as it is for 'transformative subsistence entrepreneurship' (Sridharan et al. 2014:488).

In light of the key findings, a framework (Figure 2) was developed to show visually how migrant micro-entrepreneurs use past and present social connections to gain access to resources embedded in social capital.

These entrepreneurs, therefore, leverage their social connections to establish some control over their environment, which is uncertain, to create opportunity.

The theme of life experience is elemental in the development of the personal and social makeup of the micro-entrepreneur. Life experience affects a micro-entrepreneur's past and current social relationships (Viswanathan et al. 2012, 2014), and, as Marti et al. (2013) have shown, determines the social connections the migrant micro-entrepreneur will pursue in a community setting. Life experience also produced insights into why migrant micro-entrepreneurs operate microenterprises in uncertain environments. The data revealed push and pull factors, political unrest and economic distress in respondents' home countries, and the perception of more favourable conditions to create opportunity elsewhere (Metzger \& King 2015; Wood \& McKinley 2010). It was also clear that such uncertain environments mirrored the environments that these entrepreneurs were accustomed to

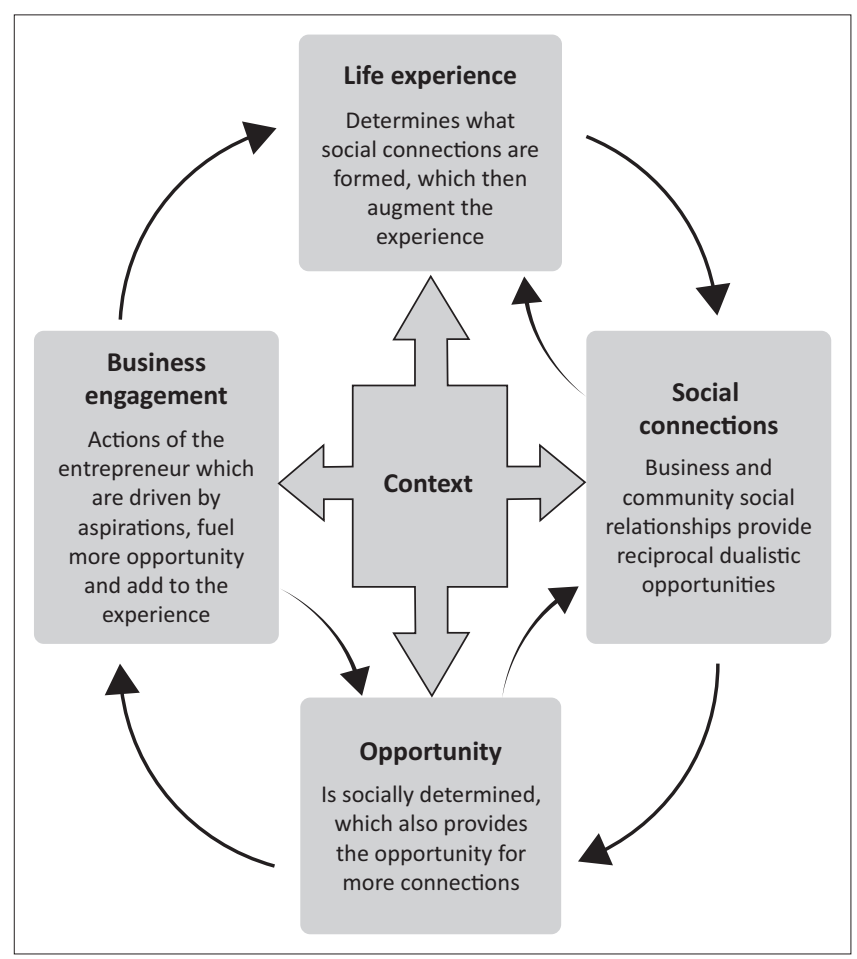

FIGURE 2: A visual representation of how opportunity, contextualised in poverty, was socially determined. 
(Marti et al. 2013). This, therefore, shows that social structures and connections within community entities can help entrepreneurs 'enhance their reach' (Ozdemir et al. 2016:49), to acquire valuable resources (Gedajlovic et al. 2013).

These social connections are made up of business and community connections, which present a reciprocal dualistic connection that entails receiving resources through social capital, but also providing resources (Daspit \& Long 2014; Gedajlovic et al. 2013; Nahapiet \& Ghoshal 1998). The value of the resources is determined by the intensity and frequency of these interactions that are either mutually beneficial through loose connections, as Leitch et al. (2013) have shown, or habitual, in tighter connections according to McKeever et al. (2014). As these social connections determine what opportunities can be created in an impoverished context, it also delivered insights on how social capital contributes to opportunity creation in these rural deprived emerging markets (Nahapiet \& Ghoshal 1998). It was clear from the data that these micro-entrepreneurs did not embed themselves into the community to contribute and extract benefits from the structural and cognitive dimension of social capital but instead used mutuality through the relational dimension to gain access in the community (Leitch et al. 2013; Marti et al. 2013).

Opportunity, therefore, originates directly from the actions of the micro-entrepreneurs which are informed by their social structures when contextualised in poverty, which also mediates the opportunity potential (Metzger \& King 2015; Wood \& McKinley 2010). It can then be argued that opportunities that are contextualised in poverty are socially determined. However, as the data have shown, the entrepreneurs should be actively engaged to benefit from any form of social capital (Botha, Carruthers \& Venter 2019).

For these reasons, business engagement emerged, which is recognised as actions of the entrepreneurs in the pursuit of a business opportunity (Gielnik et al. 2014). Engagements, however, are fuelled by aspirations, which prompted more opportunity when more social connections were formed (Gedajlovic et al. 2013). The data have shown that several microentrepreneurs shifted from subsistence to 'transformative subsistence entrepreneurship' (Sridharan et al. 2014:488), supporting Webb et al.'s (2013:2) argument that micro-enterprise capabilities have 'significant job creation potential'.

Still, a broader social structure allows the migrant microentrepreneurs access to other opportunities, which, according to Wood and McKinley (2010), are continuously shaped by the context. It can then be argued that social capital helps migrant micro-entrepreneurs extend their life experiences in a continuous cycle, which in essence allows these entrepreneurs more control over their environment.

\section{Strengths and limitations}

This study approached poverty from a 'capacity or opportunity deficiency' point of view to show how social capital plays a critical role in opportunity creation when contextualised in poverty (Bradley et al. 2012; George et al. 2012). As these micro-enterprises show 'significant job creation potential', as Webb et al. (2013:2) have suggested, government institutions can now recognise the value created in informal markets and develop programmes to support micro-enterprises so that they can slowly be integrated into the formal economy to contribute to the gross domestic product and retain value within borders (Mahadea \& Zogli 2018:7).

McKeever et al. (2014:454) stated that 'communities are the building blocks of society', which illuminates the potential that is hidden within these markets that are taken for granted. Either way, huge potential is stored in an informal market, and in this case, it was shown that economic value was diverted away from where it was originated. If these levers can be managed on a local level, the informal market can be utilised more effectively.

The study, therefore, has shown these levers to include collaborative relationships and partnerships that are grounded in mutual trust and respect (Gedajlovic et al. 2013), elements associated with the relational dimension of social capital (Calton et al. 2013; Nahapiet \& Ghoshal 1998). Government institutions and policy development bodies concerned with local micro-entrepreneurial development should take cognisance of these levers and leverage these types of mindsets to support and enable local micro-entrepreneurial growth to boost job creation and uplift poor communities (Alvarez \& Barney 2014; London \& Hart 2011; Prahalad 2012).

In light of the limitations of this study, the analysis process was prone to errors as interpretation was made by the researcher who by default used frameworks that were shaped by life experience (Shepherd \& Sutcliffe 2011). The frameworks used placed a significant emphasis on what made sense to the researcher from the perspective of the researcher's frame of mind. It could, therefore, be argued that the results, discussion and conclusion of the study were a combination of the respondents' version of what was (the raw data) and the researcher's subjective interpretation of how this was understood. Another limitation was the small sample size; however, since the study was interested in gaining insights rather than making statistical generalisations, the size of the sample is adequate (Yin 2018).

\section{Recommendations and suggestions for future research}

Although micro-enterprises are small and probably insignificant on their own, with little impact on the economy, or so it seems, it should be noted that these micro-enterprises when combined could exert substantial influence on any economy. If these micro-enterprises can be incorporated into the formal economy, driven by either local communityowned micro-enterprises or migrant micro-entrepreneurs employing local citizens, they could stimulate economic growth and add to the gross domestic product of a country (McKinsey \& Company 2016). 
It is therefore recommended that governing bodies and regulating institutions leverage micro-entrepreneurship as a vehicle for community empowerment and capability transfer to increase economic prosperity and offer a dignified existence to all that bear the brunt of poverty and poor living conditions (Ansari et al. 2012).

For future research, it would be interesting to compare local micro-entrepreneurs and their opportunities, embedded within the community, with those of migrant microentrepreneurs in the same context. In this way, comparisons can be drawn on how each group uses social capital to gain access to resources, and also to identify the conditions that favour one group over the other.

\section{Acknowledgements}

Some of the work in this article stems from Andre G. van der Walt's thesis, entitled 'Social capital effects on migrant micro-entrepreneurial opportunity creation in rural poor emerging markets: A constructivist approach', presented in partial fulfilment for the degree of Master of Business Administration in 2017.

\section{Competing interests}

The authors have declared that no competing interests exist.

\section{Authors' contributions}

A.G.v.d.W. planned and conducted the research. He reviewed the literature, formulated the research design, collected and analysed the data, made interpretations and finalised the research report. L.W. supervised the research project and reviewed sectional reports continuously to encourage a final article that has academic rigour.

\section{Funding information}

This research received no specific grant from any funding agency in the public, commercial or not-for-profit sectors.

\section{Data availability statement}

Data are stored securely and can be made available upon reasonable request.

\section{Disclaimer}

The views and opinions expressed in this article are those of the authors and do not necessarily reflect the official policy or position of any affiliated agency of the authors.

\section{References}

Alvarez, S.A. \& Barney, J.B., 2007, 'Discovery and creation: Alternative theories of entrepreneurial action', Strategic Entrepreneurship Journal 1(1-2), 11-26. https:// doi.org/10.1002/sej.4

Alvarez, S.A. \& Barney, J.B., 2014, 'Entrepreneurial opportunities and poverty alleviation', Entrepreneurship: Theory \& Practice 38(1), 159-184. https://doi. org/10.1111/etap.12078
Ansari, S., Munir, K. \& Gregg, T., 2012, 'Impact at the 'bottom of the pyramid: The role of social capital in capability development and community empowerment', Journal of Management Studies 49(4), 813-842. https://doi.org/10.1111/j.14676486.2012.01042.x

Botha, M., Carruthers, T.J. \& Venter, M.W., 2019, 'The relationship between entrepreneurial competencies and the recurring entrepreneurial intention and action of existing entrepreneurs', Southern African Journal of Entrepreneurship and Small Business Management 11(1), a214. https://doi.org/10.4102/sajesbm. v11i1.191

Bourdieu, P., 1990, The logic of practice, Polity Press, Cambridge.

Bloomberg, L.D. \& Volpe, M., 2012, Completing your qualitative dissertation: A road map from beginning to end, Sage publications, London.

Bradley, S.W., McMullen, J.S., Artz, K. \& Simiyu, E.M., 2012, 'Capital is not enough: Innovation in developing economies', Journal of Management Studies 49(4), 684-717. https://doi.org/10.1111/j.1467-6486.2012.01043.x

Calton, J.M., Werhane, P.H., Hartman, L.P. \& Bevan, D., 2013, 'Building partnerships to create social and economic value at the base of the global development pyramid', Journal of Business Ethics 117(4), 721-733. https://doi.org/10.1007/s10551-0131716-0

Creswell, J.W. \& Poth, C.N., 2018, Qualitative inquiry and research design: Choosing among five approaches, 4th edn., Sage, Thousand Oaks, CA.

Daspit, J.J. \& Long, R.G., 2014, 'Mitigating moral hazard in entrepreneurial networks: Examining structural and relational social capital in east Africa', Entrepreneurship: Theory \& Practice 38(6), 1343-1350. https://doi.org/10.1111/etap.12128

Davidsson, P., 2015, 'Entrepreneurial opportunities and the entrepreneurship nexus: A re-conceptualization', Journal of Business Venturing 30(5), 674-695. https://doi. org/10.1016/j.jbusvent.2015.01.002

Elo, S. \& Kyngäs, H., 2007, 'The qualitative content analysis process', Journal of Advanced Nursing 62(1), 107-115. https://doi.org/10.1111/j.1365-2648.2007.04569.x

Friese, S., 2016, Atlas.ti Mac - Getting started guide, Manual version: 283:2016060, Atlas.ti Scientific Software Development GmbH, Berlin, viewed 14 November 2016 from https://downloads.atlasti.com/docs/mac/ATLAS.ti_for_Mac-Getting_Started from https://downloads.atlasti.com/docs/mac/ATLAS.ti
EN.pdf?_ga $=1.184353126 .1744971863 .1471349768$

Gedajlovic, E., Honig, B., Moore, C.B., Payne, G.T. \& Wright, M., 2013, 'Social capital and entrepreneurship: A schema and research agenda', Entrepreneurship: Theory \& Practice 37(3), 455-478. https://doi.org/10.1111/etap.12042

George, G., McGahan, A.M. \& Prabhu, J., 2012, 'Innovation for inclusive growth: Towards a theoretical framework and a research agenda', Journal of Management Studies 49(4), 661-683. https://doi.org/10.1111/j.1467-6486.2012.01048.x

Gielnik, M.M., Krämer, A., Kappel, B. \& Frese, M., 2014, 'Antecedents of business opportunity identification and innovation: Investigating the interplay of information processing and information acquisition', Applied Psychology: An International processing and information acquisition, Applied Psychology: An Intern

Hall, J., Matos, S., Sheehan, L. \& Silvestre, B., 2012, 'Entrepreneurship and innovation at the base of the pyramid: A recipe for inclusive growth or social exclusion?', Journal of Management Studies 49(4), 785-812. https://doi.org/10.1111/j.14676486.2012.01044.x

Karnani, A., 2007, 'The mirage of marketing to the bottom of the pyramid: How the private sector can help alleviate poverty', California Management Review 49(4), 90-111.

Khayesi, J.N.O., George, G. \& Antonakis, J., 2014, 'Kinship in entrepreneur networks: Performance effects of resource assembly in Africa', Entrepreneurship: Theory \& Practice 38(6), 1323-1342. https://doi.org/10.1111/etap.12127

Kloosterman, R.C., 2010, 'Matching opportunities with resources: A framework for analysing (migrant) entrepreneurship from a mixed embeddedness perspective' Entrepreneurship \& Regional Development 22(1), 25-45. https://doi.org/ $10.1080 / 08985620903220488$

Lee, R., Tuselmann, H., Jayawarna, D. \& Rouse, J., 2019, 'Effects of structural, relationa and cognitive social capital on resource acquisition: A study of entrepreneurs residing in multiply deprived areas', Entrepreneurship \& Regional Development 31(5-6), 534-554. https://doi.org/10.1080/08985626.2018.1545873

Leitch, C.M., Hill, F.M. \& Harrison R.T., 2010, 'The philosophy and practice of interpretivist research in entrepreneurship', Organizational Research Methods 13(1), 67-84. https://doi.org/10.1177/1094428109339839

Leitch, C.M., McMullan, C. \& Harrison, R.T., 2013, 'The development of entrepreneurial leadership: The role of human, social and institutional capital', British Journal of Management 24(3), 347-366. https://doi.org/10.1111/j.1467-8551.2011.00808.x

Light, I. \& Dana, L., 2013, 'Boundaries of social capital in entrepreneurship', Entrepreneurship: Theory \& Practice 37(3), 603-624. https://doi.org/10.1111/ etap.12016

Lioukas, C.S. \& Reuer, J.J., 2015, 'Isolating trust outcomes from exchange relationships: Social exchange and learning benefits of prior ties in alliances', Academy of Management Journal 58(6), 1826-1847. https://doi.org/10.5465/amj.2011.0934

London, T. \& Hart, S.L., 2004, 'Reinventing strategies for emerging markets: Beyond the transnational model', Journal of International Business Studies 35(5), 350-370. https://doi.org/10.1057/palgrave.jibs.8400099

London, T. \& Hart, S.L. (eds.), 2011, Next generation business strategies for the base of the pyramid: New approaches for building mutual value, FT Press, Upper Saddle River, NJ.

Mahadea, D. \& Zogli, L.K.L., 2018, 'Constraints to growth in informal sector activities and formalisation: A case study of Ghanaian slums', Southern African Journal of Entrepreneurship and Small Business Management 10(1), a130. https://doi. org/10.4102/sajesbm.v10i1.130 
Marti, I., Courpasson, D. \& Barbosa, D.S., 2013, 'Living in the fishbowl: Generating an entrepreneurial culture in a local community in Argentina', Journal of Business Venturing 28(1), 10-29. https://doi.org/10.1016/j.jbusvent.2011.09.001

McCormick, C., 2004, 'Storying stories: A narrative approach to in-depth interview conversations', International Journal of Social Research Methodology 7(3), 219-236. https://doi.org/10.1080/13645570210166382

McKeever, E., Anderson, A. \& Jack, S., 2014, 'Entrepreneurship and mutuality: Social capital in processes and practices', Entrepreneurship \& Regional Development 26(5), 453-477. https://doi.org/10.1080/08985626.2014.939536

McKinsey \& Company, 2016, Lions on the move II: Realizing the potential of Africa's economies, McKinsey Global Institution, viewed 21 January 2019, from www. mckinsey.com/mgi

McMullen, J.S. \& Shepherd, D.A., 2006, 'Entrepreneurial action and the role of uncertainty in the theory of the entrepreneur', Academy of Management Review 31(1), 132-152. https://doi.org/10.5465/AMR.2006.19379628

Metzger, M.L. \& King, J.S., 2015, 'Extending constructivist perspectives on opportunity production through an incorporation of effectual logics', Entrepreneurship Research Journal 5(4), 323-345. https://doi.org/10.1515/erj-2014-0025

Nahapiet, J. \& Ghoshal, S., 1998, 'Social capital, intellectual capital, and the organizational advantage', Academy of Management Review 23(2), 242-266. https://doi.org/10.5465/AMR.1998.533225

Ozdemir, S.Z., Moran, P., Zhong, X. \& Bliemel, M.J., 2016, 'Reaching and acquiring valuable resources: The entrepreneur's use of brokerage, cohesion, and embeddedness', Entrepreneurship: Theory \& Practice 40(1), 49-79. https://doi. org/10.1111/etap.12103

Payne, G.T., Moore, C.B., Griffis, S.E. \& Autry, C.W., 2011, 'Multilevel challenges and opportunities in social capital research', Journal of Management 37(2), 491-520. https://doi.org/10.1177/0149206310372413

Prahalad, C.K., 2012, 'Bottom of the pyramid as a source of breakthrough innovations' Journal of Product Innovation Management 29(1), 6-12. https://doi.org/10.1111/ j.1540-5885.2011.00874.x

Ramoglou, S. \& Tsang, E.W.K., 2016, 'A realist perspective of entrepreneurship: Opportunities as propensities', Academy of Management Review 41(3), 410-434. https://doi.org/10.5465/amr.2014.0281

Rivera-Santos, M. \& Rufín, C., 2010, 'Global village vs. small town: Understanding networks at the base of the pyramid', International Business Review 19(2), 126-139. https://doi.org/10.1016/j.ibusrev.2009.07.001

Rooks, G., Klyver, K. \& Sserwanga, A., 2016, 'The context of social capital: A comparison of rural and urban entrepreneurs in Uganda', Entrepreneurship: Theory \& Practice 40(1), 111-130. https://doi.org/10.1111/etap.12107

Shepherd, D.A. \& Sutcliffe, K.M., 2011, 'Inductive top-down theorizing: A source of new theories of organization', Academy of Management Review 36(2), 361-380. https://doi.org/10.5465/AMR.2011.59330952
Sim, J., Saunders, B., Waterfield, J. \& Kingstone, T., 2018, 'Can sample size in qualitative research be determined a priori?' International Journal of Social Research Methodology 21(5), 619-634. https://doi.org/10.1080/13645579.2018.1454643

Sridharan, S., Maltz, E., Viswanathan, M. \& Gupta, S., 2014, 'Transformative subsistence entrepreneurship: A study in India', Journal of Macromarketing 34(4), 486-504. https://doi.org/10.1177/0276146714529659

Storti, L., 2014, 'Being an entrepreneur: Emergence and structuring of two immigrant entrepreneur groups', Entrepreneurship \& Regional Development 26(7), 521-545. https://doi.org/10.1080/08985626.2014.959067

Stuetzer, M., Obschonka, M., Brixy, U., Sternberg, R. \& Cantner, U., 2014, 'Regional characteristics, opportunity perception and entrepreneurial activities', Small Business Economics 42(2), 221-244. https://doi.org/10.1007/s11187-013-9488-6

Sruwig, F.W., Krüger, J. \& Nuwagaba, G., 2019, 'The influence of the business environment on the growth of informal businesses in Uganda', Southern African Journal of Entrepreneurship and Small Business Management 11(1), a200. https:// doi.org/10.4102/sajesbm.v11i1.200

Theodoraki, C., Messeghem, K. \& Rice, M.P., 2018, 'A social capital approach to the development of sustainable entrepreneurial ecosystems: An explorative study', Small Business Economics 51(1), 153-170. https://doi-org.uplib.idm.oclc.org/10 Small Business Economics

UNHCR, 2015, The United Nations Refugee Agency, viewed 19 January 2019, from https://popstats.unhcr.org/en/overview\# ga $=1.36458536 .947921381 .14738$ 37512

Venugopal, S., Viswanathan, M. \& Jung, K., 2015, 'Consumption constraints and entrepreneurial intentions in subsistence marketplaces', Journal of Public Policy \& Marketing 34(2), 235-251. https://doi.org/10.1509/jppm.14.181

Viswanathan, M., Echambadi, R., Venugopal, S. \& Sridharan, S., 2014, 'Subsistence entrepreneurship, value creation, and community exchange systems: A social capital explanation', Journal of Macro marketing 34(2), 213-226. https://doi. org/10.1177/0276146714521635

Viswanathan, M., Sridharan, S., Ritchie, R., Venugopal, S. \& Jung, K., 2012, 'Marketing interactions in subsistence marketplaces: A bottom-up approach to designing public policy', Journal of Public Policy \& Marketing 31(2), 159-177. https://doi. public policy', Journal of $P$,
org/10.1509/jppm.11.049

Webb, J.W., Morris, M.H. \& Pillay, R., 2013, 'Microenterprise growth at the base of the pyramid: A resource-based perspective', Journal of Developmental Entrepreneurship 18(4), 1350026. https://doi.org/10.1142/S108494671350026X

Wood, M. \& McKinley, W., 2010, 'The production of entrepreneurial opportunity: A constructivist perspective', Strategic Entrepreneurship Journal 4(1), 66-84. https://doi.org/10.1002/sej.83

Yin, R.K., 2018, Case study research and applications: Design and methods, 6th edn., Sage, Thousand Oaks, CA. 


\section{Appendix 1 \\ Interview guide:}

I am here to listen to your story. Tell me more about the time that led up to you opening your first store in this community.

Please share with me how this business opportunity came about.

I am also interested in your relationship with this community. Tell me more about the community leaders, your customers, friends and family members.

Did you know anyone within this community before you opened your first store?

Please share with me some of your relationships within this community after you opened your first store.

Please tell me more about your ups and downs in your business while staying in this community.

Share some of the best moments you experienced in the community while managing your business.

Also, share some of the more negative moments (not so great moments) you encountered while managing your business in this community.

Currently, do you have any relationships with people from other communities that are helpful (offer more opportunities) to your business? Please tell me more about these connections.

Can you describe to me how a typical day in your store starts?

Can you tell me more about your daily activities and how the day ends when you close your store?

Where do you want to see yourself and your business after 1 year from today? 